\title{
DEVELOPMENTS IN ENGLISH JURISPRUDENCE - 1953-1963
}

\author{
C. R. B. DUNLOP*
}

"The philosophy of law has been an integral part of the great philosophical systems; but in common with other special fields of philosophy, such as the philosophy of history, it is now with us fallen into utter neglect."1

Morris Cohen's gloomy words may strike a responsive note in the hearts of many lawyers who have had to toil their way through the grim and forbidding literature of English jurisprudence. Austin, Holland, Markby, Salmond, Paton, their names bring to mind the dismal litany of "act", "right", "duty", "ownership", "possession", which has been the subject-matter of English analytical jurisprudence.

Within the last few years, however, new writers working in England have been challenging old assumptions and giving new life to English jurisprudence. I wish to discuss their work in this essay. English jurists have ranged over many interesting and difficult problems; however, I wish to concentrate on three questions central to any philosophy of law; ${ }^{2}$

1. The nature and development of law and of legal concepts.

2. The interpretation of legal concepts.

3. Certainty and change in the law.

I must make two preliminary reservations. It is obviously too early to make any final appraisal of the contribution of the modern English writers; in this essay, I am only trying to introduce the reader to the interesting ideas now being discussed in England and to offer some criticisms.

The second reservation is best made in Dennis Lloyd's words, which I accept and apply to myself: "The present author writes as a lawyer and not as a philosopher, and is fully conscious of his lack of competence to evaluate philosophical theories."

\section{The Nature and Development of Law and of Legal Concepts.}

English jurisprudence today is much influenced by the current emphasis in English philosophy on the linguistic nature of philosophical problems, stemming particularly from the influence of the Cambridge philosopher Wittgenstein." His approach was aimed at showing how philosophical puzzlement is frequently due to confusions of language. These and other difficulties led Wittgenstein and other philosophers to treat the meaning or definition of a word as given not so much by denoting what it stands for, but by showing the ways in which a word is used in the context of a particular language. Such usage may vary within

-B.A. (Alta.), LL.B. (Alla.), LL.M. (Lond.) of the Alberta Bar, Calgary.

1 Morrls Cohen. "Jurlsprudence as a Phllosophleal Dlscipline", 1912, In Reason and Law. Coller Books, (1961) p. 139.

I I have not discussed the fascinating argument in England and the United States as to the relation between lnw and morality. The battle has primarlly centred around two foci, certain barbarous Nazt laws during the Second World War, and the recommendatlons of the Wolfenden Report an Homosexual Offenees and Prostlution. See Sir Patrick Devlin, "The Enforcement of Morals" Maccabaean Lecture in Jurisprudence, 1959; Hall WilRev. 630: Rostow (1960) Camb. L.J. 174; Hart (1961) Oxford Lawyer, Hilary Term, p. 7; The Times Newspaper. March 20th. 1961; Hart. The Concept of Law, (1961) ce. 8 and 9.

3 Lloyd, Introduction to Jurisprudience, (1959) p. xiv.

4his account of Wittgenstein's phllosophy is drawn from Lloyd, Id., at xlv-xv, at 32 ef sog. 
the same language, as a word is used in different contexts. "Don't ask for the meaning, ask for the use." Wittgenstein's epigram sums up the linguistic approach to philosophical problems.

This insight into the meaning of words was developed with specific reference to law in the Inaugural Lecture of Professor H. L. A. Hart, Professor of Jurisprudence in the University of Oxford. ${ }^{\circ}$ Professor Hart is the dominant figure in the "new wave" of English jurisprudence, because he combines a thorough and profound knowledge of philosophy with a professional training in law. Professor Hart practiced at the Chancery Bar between 1932 and 1940 before going to Oxford to assume, in succession, the positions of Fellow and Tutor of Philosophy at New College, University Lecturer in Philosophy and Professor of Jurisprudence.

Professor Hart's Inaugural Lecture, called "Definition and Theory in Jurisprudence", tackles the nature of the concepts which analytical jurists seek to define. Can we usefully ask, "What is a right?" "What is a duty?" or "What is a corporation?" Hart finds these questions to be ambiguous, partly because these words do not "have the straightforward connection with counterparts in the world of fact which most ordinary words have and to which we appeal in our definition of ordinary words".? If we seek to define "automobile", we can at least go out to the street and examine an object to which the word applies. This opportunity is lacking in the case of "duties", "rights" and "corporations".

These difficulties of definition have resulted in the development of "vast and irreconcilable theories" of juristic philosophy. Hart finds three principal theories:

1. The American Realists, he says, regard all so-called rights as simply attempts at prophecies of the probable behaviour of courts or officials. ${ }^{8}$

2. The Scandinavian jurists, ${ }^{9}$ on the other hand, regard rights as nothing real at all but as ideal or fictitious or imaginary powers.

3. Americans and Scandinavians alike attack the third theory that a right is an "objective reality"-an invisible entity existing apart from the behaviour of men.

Besides being contradictory, Hart finds these theories to be confused in aim and useless to the lawyer.

What then do we mean when we talk about right, duty or corporation? Hart explains by the use of an example.

Take the notion of a trick in a game of cards. Somebody says, "What is a trick?" and you reply "I will explain. When you have a game and among its rules is one providing that when each of our players has played a card then the player who has put down the highest card scores a point, in these circumstances that player is said to have 'taken a trick'." This natural explanation has not taken the form of a definition of the single word "trick"; no synonym has been offered for it. Instead we have taken a sentence in which the word "trick" plays its characteristic role and explained it first by specifying the conditions under which the whole sentence is true, and secondly by showing how it is used in drawing a conclusion from the rules in a particular case.10

- Lloyd, Op eit., at 43 . a Hart (1954) 70 L.Q.R. 37. On Hart generally, see Friedmann, Legal Theorv, (4th ed)., at

I Id., at 38 .

- Hart's approach to the American Realists is discussed below at 12-14.

On the Scandinavlan Realists, see Sherbanluk (1962) 2 Alta. L. Rev. 58; cf. G. Williams (1945) 61 L.Q.R. at 81-86 for a somewhat similar approach.

10 Hart. Op. cit. Supra n.6. at 47 . 
We may give the same sort of two-stage explanation to the expression "a legal right":

1. There is a legal system under the rules of which a person is obliged to do or not to do some action, which obligation is dependent on the choice of some other person.

2. A statement of the form "X has a right" is used to draw a conclusion of law in a particular case which falls under such rules.

Hart's discussion of legal concepts and rules as normative statements clearly owes much to Kelsen, and this impression is strengthened when we read Hart's later book, The Concept of Law." This book begins with a devastating criticism of John Austin's theory of law as command plus sanction.12 But Hart is careful not to dismiss the whole of Austin's work. Hart bases his own discussion ${ }^{13}$ on the Austinian insight that where there is law, then human conduct is made non-optional or obligatory. But what do we mean by "obligatory"? Hart makes a distinction between being obliged to do something and the assertion that a person has an obligation to do it. If a bank robber holds up a bank, we may say that the manager is "obliged" to open the safe. But this use of "obliged" is very different from its use in the statement, "Under Canadian law, I have an obligation to refrain from robbing banks." In the first situation, the obligatory element depends entirely on physical threat. But obligation under Canadian law to refrain from robbery remains the same, even if I believe that my robbery will not be discovered. Law is not just command plus a sanction; it is a norm in a society's legal system which system is accepted as binding by the members of the society.

Nor is it adequate to equate law to customs or to habit, or to predictions of what judges may do in the future. Laws go further in that they provide a standard by which to justify or to criticise human activity.

Hart realises that much law is not consciously accepted by every member or even by most members of a society. However, for a legal system to exist, the laws must be generally obeyed and the officials of the society must accept the fundamental laws specifying the criteria of legal validity and its rules of change and adjudication. ${ }^{14}$

The Concept of Law also includes an interesting discussion of the development of legal norms. ${ }^{13}$ Very primitive societies may have no courts or judicial officials, but they will have some general standards of behaviour which are accepted. These standards Hart calls the "primary norms of obligation". Whether we call them "laws" or not is unimportant; we can say that they resemble laws and there may also be some imperfect system of enforcement. But, in such primitive societies, three difficulties arise.

1. The rules are uncertain because there is no authoritative text or court.

11 Op. cit. Supra n.2.

12 Ibid., ce. 2-4.

13 Jbid., ce. 5-6.

14 Id. at 113. Hart acknowledges the truth in Olivecrona's point that much law, especlally of a technical nature, is accepted by most people, not because they have decided it is right and have accepted It, but because someone in a position of authority says, "That is the law". Both Hart and Ollveerona have been criticlsed for their failure to set forth any evidence to support thelr conclusions as to why people or officials obey law. See Hall (1962) 25 M.L.R. 319.

15 Hart, Op cit. Supra n.2., c. 6. 
2. The rules are static because the society has no device for changing the laws.

3. The rules are ineffective because primitive society has not developed specific agencies to maintain the rules. The diffuse social pressure which does exist is not enough to prevent feuds.

Hart says that primitive societies eventually eliminate these imperfections and their legal systems by developing three "secondary norms of obligation".

1. To obviate or reduce uncertainty, the societies recognise a "rule of recognition" which specifies some feature, possession of which by a suggested rule is taken as a conclusive affirmative indication that it is a rule of the group to be supported by the social pressure that it exerts. For example, if a judge, giving the judgment of the Supreme Court of Canada, makes the statement, "for a contract to be valid, it must be supported by consideration or by a seal", this statement is the law of Canada, if the statement was necessary to decide the case before the court. Yet if the same judge were to make the same statement during a cocktail party, the statement would then not be the law of Canada because it would not possess the feature which marks it as law, i.e. utterance by a duly constituted court as a necessary step to decision of an actual case before the court.

2. The problem of the static quality of the rules is solved by introducing . into the system a rule of change, usually by some legislature.

3. The uncertainty of primitive law is overcome by the gradual development of authoritative courts and enforcement agencies which declare and enforce breaches of the primary rules.

The important secondary norm is the rule of recognition because it determines the validity of every other norm in the society's legal system. It is not discussed by the courts, ${ }^{10}$ but it exists and can be discovered by a study of any existing society. The rule of recognition is not an assumption or a hypothesis; it is a fact. ${ }^{17}$

Professor Hart's discussion of primitive law is a considerable advance on its treatment by earlier English jurists. Austin was careful to limit his observations to "the ampler and maturer systems of refined communities."18 But the belief was not uncommon both in his time and later that primitive tribes really could not be said to have laws at all, but only customs. ${ }^{10}$

Hart's account of the development of law is not, I think, intended to lay down the constant or even usual courses of development of the legal systems of all societies. There will, for example, be societies which have well developed rules of recognition and adjudication but in which legal changes are slow, either because the legislature has no time for law re-

10 But compare the Lord Chancellor in Iolanthe (Act 1); "The Law is the true embodiment Of everything that's excellent It has no kind of fault or flaw And I, my Lords, embody the Law."

17 But ef. Fuller (1958) 71 Harv. L. Rev. 630 at 641 et seq.

18 Austln. The Uses of the Study of Jurisprudence, (1954, Library of Ideas Editlon) at 365.

10 See for example Dicey, Conflict of Laws, 7 th ed., at 9 et seq; Diamond. Primitlve Law, c. 18; cf. Hoebel, The Law of Primitive Man, cc. 2, 11, 12; Gluckman, The Judictal Process Amono the Barotse. 
form, or because the courts are not ready to change the law to accord with changing social and economic conditions. ${ }^{20}$

Nevertheless, Hart's analysis does lay itself open to the objection that it does not accord with the observations by some anthropologists of primitive law in action. Hoebel, in his Law of Primitive Man, after a detailed examination of the legal systems of eight primitive societies, concludes that primitive law is not stiff and ritualistic but on the contrary is flexible and reasonably predictable. Max Gluckman, in his fascinating study The Judicial Process Among the Barotse, ${ }^{21}$ comes to a similar conclusion. The judges in the Barotse courts keenly feel the need and duty to decide as their predecessors have decided; nevertheless Gluckman cites many cases in which the courts have reshaped the laws to fit economic and social changes in the tribe. Hart's answer to this criticism might be that he is not trying to say how any legal system does develop, but rather how it should develop to reach maturity.

\section{The Interpretation of Legal Concepts}

Professor Hart has considered this question in a number of his books and essays. A useful starting point is his essay, "Positivism and the Separation of Law and Morals", which appeared in the Harvard Law Review in 1958. ${ }^{22}$. In the course of an argument about the relationship between law and morals, Hart develops his core-penumbra theory of legal interpretation. Legal rules in a mature legal system are set out in words the meaning of which is usually clear. If a traffic by-law forbids "motor vehicles" to park on certain parts of the highway, the lawyer has no difficulty in applying the rule to a 1958 Chevrolet Sedan. But around the "core" of settled meaning exists a penumbra of debatable cases in which the words are neither obviously applicable nor obviously ruled out. Does the by-law apply to an aeroplane, a bicycle, a toy car? In cases which fall within the "core" of the word (the Chevrolet), the judge has no choice but to apply the by-law. But in the penumbral cases (the aeroplane, the toy car), the classifier must make a decision which is not dictated to him, for the facts are equivocal.

Hart develops this theory in The Concept of Law..23 "In any large group general rules, standards and principles must be the main instrument of social control, and not particular directions given to each individual separately.":" Hart admits that the core-penumbra analysis breaks down in the case of two types of law. Sometimes, legislation will set up very general standards in areas where the features of individual cases vary widely and unpredictably. Here the legislation may delegate to an administrative, rule-making body'acquainted with the varying types of case the task of fashioning rules adapted to their special needs. An example is legislation which requires an industry to charge "a fair rate" or to provide "safe systems" of work.

The second type of case where the core-penumbra theory does not apply is where the law uses a "reasonable" standard, thus leaving to in-

20 Examples might be the Supreme Court of the United States around 1900, and (in tort cases) the House of Lords after World War 11. Sec. Konefsky. The Legacy of Holmes and Brandets, (1960); Frledman, Law in a Changing Society. (1959) c. 5.

21 Gluckman, Op. cit. Supra n.19, c. 5 .

22 Hart (1958) 71 Harv. L. Rev. 593.

23 Op. ett. Supra, n.2.

24 Id. at 121. 
dividuals subject to correction by a court, the task of weighing up and striking a balance between the social claims which arise in various unanticipatable forms. The best example in English law is the use of the standard of due care in cases of negligence.: $:$

But Hart concludes that consideration of these two techniques throw into relief the characteristics of those wide areas of conduct which are controlled $a b$ initio by rules with a settled core meaning, and only a penumbra of debatable cases.

This explanation of legal interpretation Professor Hart regards as an advance over "conceptualism" which he defines as the error of ignoring the penumbral problems and of regarding the legal process as consisting pre-eminently of deductive reasoning. ${ }^{26}$

If Professor Hart is saying that the core-penumbra theory as set out above is an adequate explanation of legal or judicial interpretation then I must disagree. The definition of a specific word like "motor vehicle" varies in accordance with numerous factors, including the purpose of the statute or rule in which the word appears, the attitude of the profession or judiciary to the type of statute or rule involved, and the background of common law on which the statute is imposed. For example, section 223 of The Criminal Code provides that "Everyone who, while his ability to drive a motor vehicle is impaired by alcohol or a drug, drives a motor vehicle or has the care or control of a motor vehicle, whether it is in mo.tion or not," is guilty of an offence. What does "motor vehicle" mean here? There may be genuine core-penumbra problems concerning these words. Examples are those cases which have decided that a farm tractor is $^{27}$ or is not ${ }^{2 \mathrm{~s}}$ a motor vehicle within the meaning of this section. But a different sort of problem is raised by cases like $R$. v. Williamson. ${ }^{20}$ In that case, the accused was found intoxicated behind the wheel of the car which was in the ditch off the travelled portion of the highway. The key was in the switch and on, but the motor was not running. The car was so embedded in the snow that it would have to be towed out. The Ontario Court of Appeal held that the Crown had not proven that the car was a "motor vehicle" within the equivalent of section 222 (care or control while intoxicated). The court quoted Arsenault J. in R. v. Young;:30 "I look to the intention of the act-the safety of the public- and I cannot see that in this case the public was or could be in any way endangered."'31

Let us suppose that Williamson had been charged with illegal parking under a city by-law. I suggest that he would have been found guilty and the argument that the automobile was not a motor vehicle because it was embedded in the snow would have been summarily rejected. The difference would seem to lie in the different aims of the statutes and the

$25 \mathrm{Cl}$. Guest, In Oxford Essays in Jurtsprudence, (1961) at 178 . Speaking of words ltke "reasonable". "sultable" and "neflifent". Guest says. "These words are subject to so many psychologicai and sociological overtones that it is surprising that individual judges are able to reach any agreement as to their use at all."

26 Id., at 126.

27 R. V. Gajewskt (1951) 102 C.C.C. 115; R. v. Swarychewski (1957) 22 W.W.R.91

2R $R$ v. Owens (1950) 2 W.W.R. 1016; R. v. Urbshott (1951) 99 C.C.C. 320.

20 R. v. Willtemson (1950) 98 C.C.C. 178 (Ont. C.A.).

so R. v. Young [1939] 2 D.L.R. 62.

31 See also R. v. Broughton (1951) 100 C.C.C. 157 ; R. V. Conlin 11948] 2 W.W.R. 216; ct R. v. Weaver (1958) 121 C.C.C. 77; R. v. Jackson (1954) 110 C.C.C. 216; R. v. Thornton (1950) 25 M.P.R. 140; R. v. Talt (1951) \& W.W.R. (N.S.) 145. 
relative seriousness of the penalty. Yet the result is that the "core" meaning of "motor vehicle" is different in two criminal statutes."

The core meaning of a specific word like "automobile" seems to vary in accordance with numerous legal and extra-legal factors. $A$ fortiori, the same result should follow with general legal concepts such as possession, ownership, causation and so on. Professor Hart specifically denies that he is trying to create a jurists' "heaven of concepts", which he says is reached "when a general term is given the same meaning not only in every application of a single rule, but whenever it appears in any rule in the legal system". ${ }^{3.9}$ Yet Professor Hart, with A. M. Honoré, seem to be trying to develop exactly this sort of general concept in Causation in the Law. ${ }^{\text {a4 }}$

The authors' primary purpose is to examine the use by the courts of words like "cause", "effect", and "result" in order to identify a core of relatively well-settled common usage. The authors hasten to add that to isolate the main features of a concept latent in causal language is not to provide a code to its use, or to construct rules from which legal decisions on causal questions can be deduced."s Whatever the authors' purpose, their general conclusion is that the core meaning of the central concept of causation is the same throughout the law, and the authors display no displeasure over this result. The book may therefore have the effect of guiding courts in their use of the concept of causation and in shaping their statement of legal rules. ${ }^{36}$

After a discussion of philosophical ideas of causation, the writers attempt to describe the central notion of causation, and then to distinguish it from other meanings of the term. I will not attempt to summarise this very complex and difficult discussion. ${ }^{37}$ I must, however, mention one point. Hart and Honore find that the cause of a particular result may be distinguished from the mere conditions of that result by two factors. First, the cause has something abnormal about it, while the conditions are normal or usual. Second, there is no voluntary act intervening between the cause and the result. These two factors also set limits to the results which can be attributed to a specific cause. But how do we know when an act is "normal" or "voluntary"? The answer is that these terms are really causal notions embedded in common sense. The content of these terms is dictated, not by policy, but by common sense..$^{38}$

The rest of the book contains a detailed analysis of the concept of causation in English, Commonwealth and United States law, followed by a discussion of Continental theories of causation. By and large, the authors find that the cases bear out the core concept of causation which is set out in the first part of their book. In the fields of tort and

32 Compare the cases on fundamental breach of contract to sell "an automoblle". See Karsales (Harrow) Ltd. v. Wallis $|1956| 2$ All E.R. 866; Yeoman Credit Ltd. V. Apps (1961) 2 All E.R. 281; Guest (1961) 77 L.Q.R. 98; Sales (1953) 16 M.L.R. 318; Sicoclman v. Cunard white Star (1954) 221 F. 2d 189, per Frank J., diss, at 204-206.

ss The Concept of Lavo, supra., at 127.

34 Hart and Honore, Causation in the Law, (1959).

30 Id., at 3.

so This result is more likely because of the frequent statements of legal rules throurhout the book. See especially at 134-151 (when conduct is non-voluntary), at 131 (abnormality). at 190 (when is contributory negligence "of jegal signiflcance?"), at $281-287$ (1imitations on llability in contract), at 292 (voluntary conduct in criminal law), at 296-304 (nonvoluntary conduet), at 304 (abnormality) and so on.

97 see cc. 2-5.

88 Id., at 3, 123-5. 
criminal law, the limits to the results which are "caused" by the act of the defendant or the accused are set by the two factors mentioned above, that is, abnormality and an intervening act. This conclusion is important in tort law because it sets limits to the "direct causation" test laid down in Re Polemis.

Causation in the Law is interesting to students of jurisprudence because it is an elaborate working-out of the core-penumbra theory as applied to one general legal concept. Does it prove the utility of the corepenumbra theory? It is difficult to give a categorical answer. No doubt it is true that in the vast majority of automobile accident cases, there is no dispute about causation. If this is all the core-penumbra theory means, then even the most intransigent American Realist would accept it. But I think that Hart and Honore put their claims somewhat higher. They seem to say that, even in difficult cases, the general common sense principles of causation enable the lawyer to give a fairly firm opinion. In other words, the penumbral cases are few in number and amenable to solution by the application of the "core" principles. If this is what the writers mean, then I think that they over-state the certainty of the concept of causation.

A fundamental difficulty lies in the writers' heavy reliance on "common sense". No doubt, in the usual automobile accident, lawyer and layman alike would agree that the negligent driver "caused" the broken arm of the pedestrian he hit. One can call this common sense, if one wishes. But take a difficult case, that is, one in which there is room for disagreement and argument. For example, in Duce v. Rourke to the Defendant driver negligently injured the Plaintiff. While the Plaintiff was being removed to a hospital, tools were stolen from the Plaintiff's car. Did the Defendant's negligence cause the Plaintiff's loss? If you asked a layman this question, he would probably reply, "I don't know. It never occurred to me". He might add, "That's a question that a lawyer will have to decide"."

The common sense view of causation held by the average person is simple, fragmentary and drawn from the ordinary and not the exceptional happenings of life. Nor is it precise. The average man might say of the facts above, "Both the Defendant and the thief caused the loss." But the court, faced with such a case, must (apart from legislation) decide between the two, and on the decision rides a judgment in dollars and cents. In other words, when the judge needs assistance, an appeal to "the ordinary man's stock of general notions"12 is no help because the ordinary man has no notion, or no precise notion, about the judge's problem.'3

The same difficulty can be seen in the writers' description of those "voluntary human acts" which will be sufficient to break the chain of causation. In the section on tort, the authors say, "The general principle of the traditional doctrine is that the free, deliberate and informed act or omission of a human being, intended to produce the consequence which

39 Re Polemis [1921] 3 K.B. 560 . The book was completed before the decision of the Judiclal Committee in The Wagon Mround [1961] A.C. 398.

10 Duce v. Rourke (1951) 1 W.W.R. (N.S.) 305.

4 Egbert J. held that the answer was no. But cf. Brauer v. N.Y.C. and H.R.R. Co., cited in Causation in the Law, at 183; Patten v. Silberschein (1936) 3 W.W.R. 169.

12 Carsation in the Law, at 86.

13 Cf. Newark (1960) 76 L.Q.R. 593 ( revlew of Causation in the Law). 
is in fact produced, negatives causal connection."14 But the cases show that human conduct will not be regarded as "voluntary" within the above rule, when the conduct occurred under physical or mental compulsion, when the person acted to preserve his or another's person, property or interests, when the person acted pursuant to a legal or sometime a moral obligation, where the act was unreflective or sometimes negligent, or where the person acting was disabled in some way. ${ }^{43}$ After all these exceptional cases, the "core" meaning of "voluntary human conduct" has become so subtle and complex that I doubt if it forms part of "the stock of general notions" of any ordinary man or indeed of most lawyers. Indeed, my suspicion is that the author's "common sense notion of causation" is just a synonym for the English common law decisions on causation.

A further difficulty with Hart and Honoré's common sense principles of causation is that, even on their own description, policy considerations cannot be rigidly excluded. The writers readily admit that the defendant in a tort action may not be liable for all the damage he has caused, because policy considerations necessitate an arbitrary cut-off point. For example, in New York, the law is that a person who negligently starts a fire is liable to pay only for the first of several houses which are destroyed. This is a purely arbitrary scope rule designed to prevent an excessive burden of damages falling on the defendant. Another example is the rule that damage which stems from the impecuniosity of the plaintiff is not recoverable in a tort action.

But policy considerations appear elsewhere in the writers' account of causation. They admit that the principle of "voluntary human conduct" as a novus actus interveniens has not been applied by the courts in recent cases of statutory duty."7

In fact, the very principle of "voluntary human conduct" is so riddled with exceptions that one is led to the conclusion that it is far too short a way with causal problems. It would be better to set out openly the conflict of policies and interests which the judges have had to wrestle with in these cases, rather than suppress them beneath an abstract verbal formula with numerous exceptions.

For example, Hart and Honore cite the case of Wise v. Dunning ${ }^{48}$ as authority for the proposition that acts done by third parties under provocation by the defendant in a tort action are caused by the defendant, and the intervening human action is not voluntary. The facts were that the Catholics of Liverpool reacted to a Protestant preacher's insulting speeches by committing breaches of the peace. It was held that, the disturbances being the consequence of the inflammatory speeches, there were sufficient grounds for binding the preacher over. The case is a criminal law decision.

But suppose that a property owner had sued the preacher for the cost of a window broken during the riot? Would the result necessarily have been the same? Suppose that an action had been brought by the estate of someone killed during the riot? The results in these cases might be

14 ra., at 129 .

46 Id., at 134-148; cl. at 296-304 (criminal law).

16 The Llesbosch Dredger v. Edison (Ownors) [1933] A.C. 449.

17 Causation in the Law, p. 133. An example is Stapley v. Gypsum Mines [1953] A.C. 663.

48 Whe v. Dunning [1802] 1 K.B. 167; Causation in the Law, at 140. 
different because the interests and the type of law involved are different, and it is quite probable that the court might state that the preacher had not caused the damage for the purposes of this type of legal action.

The writers' "common sense principles of causation" break down completely in their discussion of causation and contributory negligence. Here Hart and Honore argue that the old common law rule that contributory negligence was a complete bar to recovery was common sense, ${ }^{\text {" }}$ but that the last clear chance doctrine was not," although the latter seems to have been a crude attempt at common law to ameliorate the injustice of Butterfield v. Forrester. ${ }^{31}$ It seems to me that the lack of common sense of the common law contributory negligence rule is demonstrated by its almost universal rejection by legislatures in favour of the statutory system of apportionment.

The above criticisms lead to the conclusion that Causation in the Law is not an unqualified success as an application of the core-penumbra theory to general legal concepts.

The English writers in jurisprudence are well aware of the modern criticisms of "conceptualism", and there is some evidence of a growing sympathy in England with American sociological jurisprudence. For example, D. R. Harris, writing in the Oxford Essays in Jurisprudence on Possession, 32 finds that the English cases preclude us from laying down any condition as absolutely essential for a judicial ruling that a man possesses something. (In other words, no "core" meaning at all.) What the decisions do reveal is a series of factors which the courts consider in possession cases and which may receive different emphasis depending on the policy behind the particular rule.

On the other hand, A. M. Honoré, in his essay on Ownership, ${ }^{s 3}$ attempts a thoroughly conceptualistic description of "the liberal concept of ownership", which may be an accurate reflection of the common law decisions and dicta on ownership, but does not seem adequate to me as an account of property in the modern law, especially the law of corporations" or taxation.

It would seem that Llewellyn's call for a regrouping of cases and legal situations into narrower categories ${ }^{38}$ has been heeded by some, but by no means most or all analytical jurists in England today.

\section{Certainty and Change in the Law}

Legal philosophy over the past thirty years has centered around two difficult and related questions; "How certain is the law?" and "How does the law change?" No practising lawyer would suggest for a moment that he could find in the books the one conclusive answer to every legal problem with which he is faced. But lawyers have sometimes tended to regard certainty as the supreme quality of the common law. This attitude

10 Causation in the Law, at 195-200, 201.

so Id., at 207.

51 Butterfield v. Forrester (1809) 11 East. 60. See MacIntyre, (1940) 18 Can. Bar Rev. 665; (1955) 33 Can. Bar Rev. 257.

s2 Oxford Essays in Jurisprudence, at 69.

63 Id., at 107. st Cf. Berle and Means, Modern Corporation and Private Property. (1933): Gower. Modern

5s K. Lewellyn. "Some Reallsm About Realism" (1931) 44 Harv. L. Rev. 1222, In Lloyd. Introduction to Jurisprudence, at 220. 
was stated emphatically by Professor Wade in "The Concept of Legal Certainty"." Writing in the early days of the Second World War, Wade said;

Law exists to insure the order which the forces in control of a society desire to impose. Its object is uniformity of action so that one member of the society may know how, in certain circumstances, another is likely to behave, this being the essence of sccurity. Subsidiary to the concept of order is that of justice ... For one coming from another field either to the practice or the study of law, surely the most impressive thing is the scientific form to which it has been reduced, the severity and exactitude of its processes and its ability to provide formulae, mostly short and precise in language, by which millions of men and women unquestioningly regulate their commonest doings.:-

In the article quoted, Professor Wade was criticising a group of American jurists who have been described as the Realists. These and other jurists find the ideal of certainty unsatisfactory as a basis for a complete and accurate description of law. The legal result in any particular fact situation is uncertain because (1) the facts of the case are never definitely known until found by the judge;ix and (2) the judge or lawyer has some choice in his statement and application of the law because of the indeterminate nature of legal terms and rules, different theories of seeking the ratio decidendi and varying statements of the ratio in different judgments in the case or even in the same judgment. ${ }^{i 3}$

This article is not the place to attempt an appraisal of the achievements of modern American jurists. I wish instead to ask whether the new English writers are sympathetic to American Sociological or Realist jurisprudence.

It must be admitted that the English reaction to American jurisprudence has been somewhat shallow. Roscoe Pound is widely recognised as an important figure in legal philosophy. But I know of no English writer who could be described as writing sociological jurisprudence today, ${ }^{, 0}$ although Pound's influence is acknowledged by many. ${ }^{11}$ But if Pound is ignored, the work of the American Realists has been the subject of active criticism at the hands of the English writers.

The early critics of the Realists were quick to seize on some of the more flamboyant statements of Jerome Frank, such as his reliance on behaviourist psychology, and to attribute these statements to all Realists." The Realists were accused of excessive faith in statistics and fact studies, ${ }^{13}$ and in the application of scientific methods to law. Llewellyn proved these charges false thirty years ago, "1aia and yet these hoary fallacies continue to appear in English discussions of American jurisprudence. Perhaps the most serious charge levelled against the American Realists' writing was that it over-emphasised uncertainty in the legal process. To many, the issue between the American and the English writers was

30 Wade (1941) 4 M.L.R. 183 at 185, 197.

67 For a more moderate statement, see Hart, The Concept of Law, at 127

os What Jerome Frank called "fact scepticism". See Frank. Law and the Modern Mind (1949 ed.): Court on Trial, (1949).

60 "Rule sceptlclam". See esp. Lleweilyn (1931) 44 Harv. L. Rev. 1222 (1940) 40 Col. L. Rev, 581: Llewellyn, The Common Law Tradition, Deciding Appeals, (1960); Stone, (1959) 22 M.L.R. 597 .

60 As Pound descrlbes It In his Jurisprudence, (1959). c. 6.

61 See for exnmple Graveson, Status in the Common Law, Introduction (1953): Dowrick (1963) 26 M.L.R. 106; Hall (1962) 25 M.L.R. 319; Lloyd. Introduction to Jurisprudence, at xvi-xvil. 62 Goodhart, "Some American Interpretatlons of Law" in Modern Theories of Law, (1933),

os Goodhart, Ibid., Allen. Lat in the Making, 6th ed., at 47 et sea.

nila Supra, n. $\mathbf{5 5}$. 
simple; either the judges and lawyers are controlled by imperative and largely clear legal doctrine, or there is no rule of law but only unfettered discretion in the judge. Even Frank rejected this impression of Realism in his Introduction to the 1949 edition of Law and the Modern Mind. Yet Professor Hart seems still to express his criticism of Realism in this oversimplified form. Hart devotes a substantial part of The Concept of Law and Causation in the Law to "rule secpticism". In The Concept of Law, Hart writes, ${ }^{\text {st }}$

Rule-scepticism has a serious claim on our attention, but only as a theory of the function of rules in judicial decision. In this form, while conceding all the objections to which we have drawn attention, it amounts to the contention that, so far as the courts are concerned, there is nothing to circumscribe the area of open texture: so that it is false if not senseless, to regard judges as themselves subject to rules or "bound" to decide cases as they do. They may act with sufficient predictable regularity and uniformity to enable others, over long periods, to live by courts' decisions as rules. Judges may even experience feelings of compulsion when they decide as they do, and these feelings may be predictable too; but beyond this there is nothing which can be characterised as a rule which they observe ... The sceptic's conception of what it is for a rule to exist, may thus be an unattainable Ideal, and when he discovers that it is not attained by what are called rules, he expresses his disappointment by the denial that there are, or can be, any rule.

Professor Hart goes on to quote from The Bramble Bush;":s "Rules are important so far as they help you to predict what judges will do. That is all their importance except as pretty playthings."

It seems to me that these paragraphs give a most misleading view of American Realism. The American Realists were not trying to write legal philosophy; Frank expressly denied any such purpose. ${ }^{\circ 6}$ Frank and his generation of lawyers and law teachers were rebelling against an overmechanical and formal approach to law which had left American law burdened with such completely abstract and unrealistic doctrines as Beale's rules of Causation ${ }^{17}$ and the First Conflicts Restatement. These rules and doctrines were not helpful to the practising lawyer and to the judge because they failed to tell them what should be the answer in a particular fact situation. The fault lay partly in the over-generalization of the rules themselves and partly in the presence in the legal process of other extra-legal factors which influence discisions. But this is not to say that no legal rules exist.

Professor Hart cites one sentence from Llewellyn's The Bramble Bush to support his description of rule-scepticism. Yet surely the whole purpose of The Bramble Bush was to help law students in extracting legal rules and doctrine from the decided cases. When Llewellyn said that rules are important only as predictions of judicial action, he was doing no more than advising against an over-academic approach to law. Law in books is not always the same as law in action and Llewellyn was directing his advice to students who hoped to practice law.

Llewellyn's essay on Realism in the 1931 Harvard Law Review ${ }^{08}$ seems to affirm the existence of legal rules while emphasising that the rules

of The Concept of Law, at 135. See also Hart's discussion of "scorer's discretion", at 138-144. Cf. Causation in the Lato, esp, at 3-7, 123-125, the whole of chapter $x$, esp. at 261 . ("They inslst that the declsions of courts on the extent of a wrongdoer's libility are not and shall not be reached by the application of any general princlples but by the exerclse of the sense of judgment. unhampered by legal rules on the facts of each case.") os Llewellyn, The Bramble Bush, (1945).

ds Preface, Law and the Modern Mind, (1949 ed.) in Lloyd, Op. cit, supra, n.3 at 213-217. or Beale, The Proximate Consequences of an Act" (1920) 33 Harv. L. Rev. 633.

os Llewellyn, Loc. cit. supra, n.59. 
may be too broadly worded in the texts and may not be "the heavily operative factor in producing court decisions." His last book, The Common Law Tradition, Deciding Appeals, "was largely an attempt to show how the established body of legal doctrine can be, and is, reworked and rethought by successive generations of lawyers and judges.

A somewhat more sympatheic view of American jurisprudence is put forward by A. G. Guest in his essay on "Logic in the Law", published in Oxford Essays in Jurispridence. ${ }^{70}$ Guest begins by referring to the traditional lawyers' distrust of logic. This distrust is supported by three specific argument: (1) Decisions cannot be arrived at simply by deduction from existing legal principles; (2) legal rules are too fluid and uncertain to support any logical inferences which would be drawn from them; and (3) the whole conception of law as a simple, unitary, logically consistent system is at least an impracticable idea, if not an illusory fetish.

Guest admits that there is considerable truth in these contentions. But they do not affect the place of logic in the law.

Logic is concerned merely to demonstrate the correctness or incorrectness of the deductions or inferences made, and, although it may be necessary for this purpose to inquire into the logical form of the propositions advanced, it is not necessary to assert their truth or to define the sources from which they are to be drawn. ${ }^{71}$

Guest goes on to discuss three types of logic used in legal reasoning. They are deductive reasoning, inductive reasoning and reasoning by analogy, although legal reasoning may also be the product of intuition, emotion or prejudice.

Guest is greatly influenced in his discussion of analogy by E. H. Levi's An Introduction to Legal Reasoning. ${ }^{72}$ Levi regards the basic pattern of legal reasoning as reasoning by example, reasoning from case to case. It is a three-step process: (1) Similarities are seen between cases; (2) the rule of law inherent in the first case is announced; (3) then the rule of law is made applicable in the second case. This system of reasoning is technically imperfect in that the rules may, and do, change. This is why reasoning by example is the basic type of legal reasoning, because change is "the indispensable dynamic quality of law." The rules change as the rules are applied. The consistency and continuity of law is thus to be found less in the rules than in the legal forum and in the accepted process by which social disputes and conflicts are settled. Levi illustrates his discussion with a fascinating analysis of the developments and changes in tort law which preceded the decision of Cardozo C.J. in MacPherson v. Buick. ${ }^{33}$

Guest agrees with Levi that legal reasoning by analogy enables judges to change the law and that the law is, to this extent, uncertain. But Guest hastens to add that the process is not entirely guesswork.

Just as in a game of chess there are rules which restrict the movement of the pleces, so too is legal reasoning the judges work within certain rather ill-defined conventions. These conventions are largely a matter of judicial experience, and

69 Lewellyn, Op. cit. supre, n.59.

io Oxford Bssays in Jurisprudence, at 176

11 Id., at 178-9.

i2 Levi, An Introduction to Legal Reasoning, (1949). For a less sympathetlc approach, see Cross, Precedent in English Laro, (1961), esp, at 201.

Ts MacPherson v. Butck (1916) III N.E. 1050 (N.Y.C.A.). 
they perhaps mean no more than that a judge can distinguish between a "good" and a "bad" legal argument. But any major violation of the conventions would cause such an upheaval in accepted assumptions that it would destroy the game. ${ }^{i 4}$

\section{Conclusions}

In the essay quoted at the beginning of this paper, Morris Cohen was advocating co-operation between lawyers and philosophers in the development of a philosophy of law. It is precisely this co-operation which is making modern English jurisprudence so interesting and challenging. One result of this co-operation has been a new insight into the nature and meaning of legal concepts. The development of law in primitive society has been found to cast light on our understanding of international law. Perhaps the greatest advance in English juristic thought has been a new, more balanced understanding of the achievements as well as the weaknesses in the work of John Austin.

But English jurisprudence still suffers from an over-emphasis on law in the books, and a corresponding disinterest in law as a social and economic institution, moulded by and moulding the society of which it is a part. The linguistic approach to law is essentially an effort to define words on a page and is thus a continuation of the English tradition. But no amount of study of the words of a textbook will give the student any ideas of the working out of the law in the courts or of the effects of law on business or society.

A result of this imbalance is that the English have never produced a thorough descriptive study of the methods and techniques by which English judges make decisions. : Another result is that English law students' texts, especially on subjects like Bills and Notes and Company Law, ${ }^{70}$ are still written as collections of abstract legal precepts and with very little mention of the business and economic context in which that law is used today. ${ }^{7}$

Nevertheless, as we have seen, the English writers today are making tentative excursions into American Sociological and Realist Jurisprudence. Let us hope that the next decade sees the birth of a real partnership between American and English writers and teachers of jurisprudence, a partnership which cannot but enrich and deepen legal philosophy on both sides of the Atlantic.

is Oxford Easays in Jurisprudence, at 191-2; cl. Llewellyn The Common Lav Tradition, Deciding Appeals. esp. discussion of major steadying factors in appellate courts.

75 Such a study seems improper to some English writers. See F. A. Mann, (1958) 21 M.L.R. 458. (review of Blckel, Unpublished Opinions of Mr. Justice Brandeis).

is With the exception of Gower, Modern Company Law, which is still regarded in Dngland as a rather "radical" book.

it Cf. lor example Braucher and Sutherland, Commercial Transactions, (2nd ed., 1958). 